\title{
Registered voluntary collective agreements in New Zealand.
}

\author{
F.J.L. Young*
}

This study reports the results of a survey of voluntary collective agreements (VCA s). It reports the number of workers covered by VCA s and analyses the agreements by industry, region and union involvement.

Since 1894 , New Zealand's formal system of “private sector" industrial relations has relied on the use of industrial conciliation and complulsory arbitration to regulate industrial conflict. Only since the late 1960s, however, has attention been directed towards collective bargaining (significantly called direct bargaining) as an alternative to formal statutory procedures.

A number of observers have argued that the New Zealand system of industrial relations is in transition (Walsh, 1982; Wilson, 1981 and Young, 1975). Their different interpretations centre on a breakdown or weakening of the formal system of industrial relations. In the short run this has been associated with increasing Government involvement in the processes of wage fixing and adjustment. In the longer run, the downgrading of formal procedures may well point to institutional changes leading to some form of "free" collective bargaining. Such interpretations are necessarily rather impressionistic given the dearth of hard data on many aspects of industrial relations in New Zealand. The purpose of this article is to report on an attempt to establish some of the dimensions of the growth of voluntary collective bargaining in recent years.

\section{Methodology}

The study was based on a survey undertaken by the writer and his research assistants over the summer vacation $1980 / 81$ and processed during 1981/82. It set out to determine the number of employees covered by voluntary settlements registered with the Arbitration Court. When work commenced, it was believed that around 40 percent of instruments falling within the purview of the Court resulted from voluntary negotiations; no one, however, could estimate the number of persons covered by them. Still less was it possible to relate such settlements to the size of work groups, their industrial and geographic distribution or union involvement.

Initially a list of current voluntary collective agreements was compiled from Department of Labour records. This was double-checked with the help of Arbitration Court records. At the same time, all instruments registered with the Arbitration Court since 1973, and still in force, were sorted into 3 categories using the Appendix to the Book of Awards. This initial categorisation of instruments can be summarised as follows:

* F.J.L. Young was Professor of Industrial Relations at Victoria University of Wellington and Director of the Industrial Relations Centre there until March 1983. He is now Permanent Arbitrator in Fiji. He gratefully acknowledges help received from his research assistants, Denise Freebairn, Wai Meng Foo and Sherry Phipps as well as the useful comments received on his initial draft from Doug Martin, John McCarthy, Paul Stapp and the Journal's two referees. 


\begin{tabular}{lrr} 
Awards & 357 & $(30.6 \%)$ \\
Voluntary collective agreements & 698 & $(59.6 \%)$ \\
Composite agreements & 66 & $(5.6 \%)$ \\
Voluntary agreements & 49 & $(4.2 \%)$ \\
\cline { 2 - 3 } & 1170 & $(100 \%)$ \\
\cline { 2 - 2 }
\end{tabular}

The summary points to the predominance of voluntary settlements since the passage of the Industrial Relations Act in 1973. Less than one third of the instruments made between 1973 and 1979 were awards of the Arbitration Court.

Interesting though the latter finding was, it did not throw any light on the point at issue, the number of employees covered by voluntary settlements. To arrive at an estimate of the latter figure, it was decided to determine what voluntary collective agreements under sections 65 and 66 of the Industrial Relations Act had emerged from the 1979/80 wage round. The agreements concerned were gathered together, the addresses of the employers involved were obtained and a simple questionnaire prepared. The questionnaire took the following form:

\section{Voluntary Collective Agreements}

The Industrial Relations Centre, Victoria University of Wellington, with the cooperation of the Department of Labour, is conducting a survey to ascertain the number of workers and employment sectors covered by voluntary collective agreements.

We would appreciate your co-operation if you would indicate the number of workers in your organisation covered by the following collective agreement and return this letter in the enclosed stamped addressed envelope.

(Title of voluntary collective agreements)

Number of workers covered:

$$
\begin{array}{r}
50 \text { or less } \\
51-100 \\
101-200 \\
201-250
\end{array}
$$

$$
\begin{gathered}
251-500 \\
501-1000 \\
1000+
\end{gathered}
$$

After the title and date of each instrument had been typed on to a questionnaire, 466 questionnaires were mailed out to prospective respondents in February 1981. Over the next few weeks almost 85 percent of the questionnaires were returned completed. A follow-up to those who did not respond initially eventually raised the response rate to 96 percent. Summarisation of the data provided by respondents made it possible to compile Table 1 below.

Table 1 Worker coverage and size of work group

\begin{tabular}{cc}
\hline Number of workers & Number of VCAs \\
\hline 50 or less & 277 \\
$51-100$ & 51 \\
$101-200$ & 38 \\
$201-250$ & 6 \\
$251-500$ & 29 \\
$501-1000$ & 9 \\
1000 or more & 2 \\
TOTAL & $412^{\text {(a) }}$ \\
\hline
\end{tabular}

Note: (a) In addition to the 15 questionnaires which were not returned, a further 39 were not used for the following reasons: 3 were returned by Post Office "address unknown", 2 were blank, 1 was spoiled, 1 reported the VCA amalgamated with a composite agreement, 11 had expired or been cancelled, 2 concerns were in liquidation, 6 had closed down, 10 reported no employees, 2 reported VCA no longer in use and 1 said that it had never entered into a VCA. 
Table 1 indicates that during the period under review, voluntary collective agreements were most commonly associated with small work groups. About 67 percent of these instruments covered groups of 50 workers or less. The percentage rose to 79 percent if work groups of 100 or less were considered. The latter finding, however, should not be overstressed. Some 40 of the voluntary collective agreements covered more than 250 workers, a total of at least 10000 persons. With the survey covering a maximum of just under 48000 persons, this implies that 21 percent of those involved were found in New Zealand's larger enterprises. It also suggests that voluntary collective bargaining within the formal system of industrial relations (i.e. involving registered instruments) was limited to between 4 and 5 percent of surveyed employees ${ }^{2}$ in the early 1980 s.

Table 2 Voluntary collective agreements by industrial classification

\begin{tabular}{|c|c|c|c|c|}
\hline \multirow[b]{2}{*}{ Industrial classification } & \multirow[b]{2}{*}{$\begin{array}{l}\text { Number } \\
\text { of VCAs }\end{array}$} & \multicolumn{3}{|c|}{ Employment } \\
\hline & & $\begin{array}{c}\text { Under VCAs } \\
\text { mid range } \\
\text { (1) } \\
\end{array}$ & $\begin{array}{c}\text { Surveyed } \\
\text { workforce } \\
(2) \\
\end{array}$ & $\begin{array}{c}\text { Percentage } \\
\text { under VCAs } \\
(1) /(2)\end{array}$ \\
\hline \multicolumn{5}{|l|}{ 1. Agriculture, Forestry and } \\
\hline Fishing & 3 & 795 & 8189 & 9.7 \\
\hline 2. Mining and Quarrying & 9 & 1112 & 3666 & 30.3 \\
\hline 3. Manufacturing & 238 & 20610 & 294729 & 6.9 \\
\hline 4. Electricity, Gas and Water & 8 & 818 & 15517 & 5.3 \\
\hline 5. Construction & 7 & 476 & 55629 & 0.8 \\
\hline \multicolumn{5}{|l|}{ 6. Trade, Restaurants and } \\
\hline Hotels & 6 & 351 & 193406 & 0.2 \\
\hline 7. Transport and Communications & 26 & 1481 & 96172 & 1.5 \\
\hline \multicolumn{5}{|l|}{ 8. Finance, Insurance, Real } \\
\hline Estate etc. & 15 & 382 & 68008 & 0.6 \\
\hline \multicolumn{5}{|l|}{ 9. Community and Personal } \\
\hline Services & 100 & 9639 & 297092 & 3.2 \\
\hline Total & 412 & $47912^{(a)}$ & 1032407 & 4.6 \\
\hline
\end{tabular}

Note: (a) Maximum employment

\section{Industrial distribution of instruments}

Reclassification of the data under review by industry suggests that voluntary collective bargaining within the formal system was by no means an extensive practice. At the time of the survey, Table 2 indicates that voluntary collective agreements could certainly be found in each of the 9 industrial classifications used by the Department of Labour in its own annual employment survey. The majority of these agreements, were, however, clustered in either manufacturing or community and personal services. Out of a total of 412 agreements, these two classifications accounted for 338 (or 82 percent). Almost 58 percent were found in manufacturing and a further 24 percent in the other classification. Elsewhere, the incidence and coverage of voluntary collective bargaining cannot be described as significant with the possible exception of mining and quarrying where nearly a third of the small surveyed workforce was covered.

2 The Annual Employment Survey reported 1032407 wage and salary earners ( 887292 full time employees and 145115 part time employees) in surveyed industries on 28 February 1980 (see Labour and employment gazette, 30(3) 1980, p. 45). The total surveyed labour force at that time included an additional 78957 working proprietors. The latter have not been included in calculating the percentages of persons covered by voluntary collective agreements. 
Table 3 Voluntary collective agreements by employment districts

\begin{tabular}{lrc}
\hline $\begin{array}{l}\text { Employment } \\
\text { district }\end{array}$ & $\begin{array}{c}\text { Number } \\
\text { of VCAs }\end{array}$ & $\begin{array}{c}\text { Middle of } \\
\text { range of employment } \\
\text { under VCAs }\end{array}$ \\
\hline Whangarei & 11 & 627 \\
Auckland & 98 & 10296 \\
Manukau & 29 & 3451 \\
Hamilton & 14 & 1466 \\
Tauranga & 7 & 426 \\
Rotorua & 35 & 396 \\
Gisborne & 3 & 56 \\
Napier & 5 & 150 \\
Hastings & 7 & 118 \\
New Plymouth & 12 & 425 \\
Wanganui & 8 & 351 \\
Palmerston North & 6 & 354 \\
Masterton & 0 & - \\
Lower Hutt & 14 & 2566 \\
Wellington & 46 & 4327 \\
Blenheim & 3 & 90 \\
Nelson & 18 & 410 \\
Greymouth & 1 & 37 \\
Christchurch & 50 & 861 \\
Timaru & 9 & 306 \\
Dunedin & 19 & 629 \\
Invercargill & 17 & 879 \\
Total & 412 & 912 (a) \\
\hline & &
\end{tabular}

Note: (a) Maximum employment

\section{Geographic distribution of instruments}

A further refinement of the data by employment district is similarly revealing. Some 187 , or 45 percent, of voluntary collective agreements were found in the Auckland, Manukau, Wellington and Lower Hutt Employment Districts. Over 43 percent of the employees covered by such documents were to be found in these districts. The addition of a further four employment districts (Hamilton, Rotorua, Christchurch, Invercargill) raised the number of agreements to 303 , or 74 percent of the total, and employee coverage to over 66 percent. It is also evident that the bulk of voluntary collective agreements and the greater proportion of employees covered were to be found in the North Island.

\section{Trade union involvement}

A further reclassification of data was made to determine the extent of trade union commitment to voluntary collective bargaining. This immediately threw up a number of difficulties. The classification found in the appendix to the Book of Awards proved extremely broad and misleading for the purposes in hand. Secondly, a number of collective agreements covered work on several locations. Thirdly, in the case of the special group of VCAs, the composite agreements, it was necessary to determine the frequency of involvement of particular unions in the 30 agreements surveyed. All these difficulties made it impossible to construct a single summary table. The data were consequently arrayed in Tables 4 and 5. 


\section{Categories of union}

Table 4 employs the Department of Labour categorisation of industrial unions of workers in an attempt to overcome the difficulty arising from the classification found in the appendix to the Book of Awards. Whilst this does not overcome all difficulties associated with classification ${ }^{3}$, it probably provides a better categorisation for the purposes in hand. In Table 4, each category of union is related to the number of surveyed VCAs to which it was a party. These data are also arrayed by the number of locations covered by the agreements and the midpoint in the reported range on union membership. For analytical purposes, it has been assumed that the range of employment shown up by the survey was synonymous with union membership. This seems by no means a heroic assumption given the breadth of application of the unqualified preference clause although it does ignore certain exemptions from union membership (which are likely to be very small in number).

It will be noted that Table 4 covers 316 VCAs whereas previous tabulations have shown 412. Not all the difference between the two totals is explained by the existence of the composite agreements detailed in Table 5 . The difference between the total shown in Table 4 and the total in the earlier tables is explained mainly by the fact that quite a number of the agreements shown in Table 4 applied in several locations. The 412 agreements reported by respondents to this survey thus prove in fact to have been 316 documents applicable to 382 locations, plus the 30 composite agreements yet to be discussed.

Table 4 indicates that VCAs were negotiated by a wide range of unions at the time of the survey. If one sets aside the miscellaneous group of incorporated societies and the two hybrids, several interesting points emerge. Firstly, VCAs were entered into by 43 of the 84 categories of industrial unions of workers recorded by the Department of Labour. Despite this, voluntary collective bargaining leading to registered agreements seems to have been an uncommon practice within 35 of the 43 categories of union covered in Table 4 . VCAs were found most frequently in no more than eight of the 43 categories: viz., clerical workers, drivers, electrical workers, engine drivers, engineers and allied workers, freezing workers, labourers and local body officers. These eight categories provided 196 VCAs covering at least 17524 union members. In terms of the total sample this amounted to 62 percent of the instruments and 40 percent of union membership.

\section{Composite agreements}

Table 5 summarises union involvement in the 30 composite agreements revealed by the survey. Again, close examination of the documents showed a variance between the number of agreements and the number of locations where they applied. In fact, there were only 25 composite agreements but they covered 30 locations. A further complication arose from the differing numbers of unions which were parties to a particular document. It was consequently decided to construct Table 5 to show the total number of unions involved in each composite agreement and the frequency of involvement of each union in composite agreements. The number of unions which were parties to a particular document ranged from two to five. The frequency of union involvement in composite agreements ranged from one instance to 13 . Engineers, electrical workers, drivers, labourers, carpenters and storemen and packers were the most frequently involved groups.

The requirements of Table 5 meant that considerations of union membership (employment) had to be ignored. On the 30 locations involved, the composite agreements covered a maximum of 5035 persons.

3 The categories of union listed in the Department of Labour Annual Report are by no means coextensive with all occupations. Storemen and packers, for example, are found in that category of union and in shop employee unions. 
Table 4 Industrial unions of workers involved in voluntary collective bargaining (Department of Labour Categorisation)

\begin{tabular}{|c|c|c|c|c|}
\hline \multirow[b]{2}{*}{ Category of union } & \multirow{2}{*}{$\begin{array}{c}\text { Department of } \\
\text { Labour } \\
\text { index number }\end{array}$} & \multicolumn{2}{|c|}{ Number of } & \multirow{2}{*}{$\begin{array}{c}\text { Middle of range } \\
\text { employment } \\
\text { under VCAs } \\
\end{array}$} \\
\hline & & VCAs & Locations & \\
\hline Abattoir Workers & 1 & 1 & 1 & 150 \\
\hline Asbestos Workers & 4 & 1 & 1 & 375 \\
\hline Biscuit \& Confectionery Emp. & 7 & 1 & 1 & 25 \\
\hline Bootmakers \& Repairers & 8 & 1 & 1 & 375 \\
\hline Carpenters \& Joiners & 11 & 7 & 8 & 536 \\
\hline Cleaners, Caretakers, etc. & 13 & 4 & 4 & 150 \\
\hline Clerical Workers & 14 & 11 & 25 & 1683 \\
\hline Coachworkers & 16 & 2 & 2 & 100 \\
\hline Coalmine Workers & 17 & 1 & 1 & 25 \\
\hline Dairy Employees & 19 & 4 & 4 & 276 \\
\hline Drivers & 21 & 19 & 27 & 2172 \\
\hline Electrical Workers & 22 & 11 & 11 & 730 \\
\hline Engine Drivers & 23 & 51 & 55 & 1564 \\
\hline Engineers \& Allied Workers & 24 & 41 & 56 & 6960 \\
\hline Fish Trade Employees & 28 & 1 & 1 & 25 \\
\hline Flight Planners & 29 & 1 & 1 & 25 \\
\hline Foodstuffs ... Mfg Employees & 31 & 8 & 9 & 288 \\
\hline Freezing Workers & 32 & 12 & 12 & 383 \\
\hline Furniture Trade Employees & 33 & 1 & 1 & 150 \\
\hline Gasworks Employees & 34 & 1 & 1 & 25 \\
\hline Harbour Boards Employees & 36 & 1 & 1 & 25 \\
\hline Hotel \& Restaurant Employees & 38 & 7 & 9 & 326 \\
\hline Labourers & 42 & 23 & 26 & 1345 \\
\hline Laundry Employees & 43 & 3 & 10 & 696 \\
\hline Lime \& Cement Workers & 44 & 1 & 1 & 150 \\
\hline Local Body Officers & 45 & 28 & 34 & 2687 \\
\hline Match Factory Employees & 46 & 1 & 1 & 25 \\
\hline Merchant Service Employees & 47 & 3 & 4 & 75 \\
\hline Painters \& Decorators & 52 & 5 & 5 & 552 \\
\hline Plumbers \& Gasfitters & 56 & 2 & 2 & 50 \\
\hline Printing Trade Employees & 57 & 4 & 5 & 576 \\
\hline Pulp \& Paper Workers & 59 & 5 & 5 & 898 \\
\hline Rubber Workers & 62 & 2 & 2 & 526 \\
\hline Rural Workers & 63 & 4 & 4 & 225 \\
\hline Seamen & 67 & 1 & 1 & 25 \\
\hline Shop Assistants & 69 & 4 & 4 & 501 \\
\hline Sports Goods Employees & 70 & 2 & 2 & 50 \\
\hline Stewards \& Hostesses (Air) & 71 & 1 & 1 & 25 \\
\hline Storemen \& Packers & 73 & 8 & 8 & 225 \\
\hline Theatres \& Places of Amsmnt. & 77 & 2 & 2 & 50 \\
\hline Timberyards \& Sawmills & 78 & 9 & 11 & 2421 \\
\hline Watersiders, Stevedores, etc. & 80 & 2 & 2 & 50 \\
\hline Woollen Mills Employees & 81 & 2 & 2 & 150 \\
\hline \multicolumn{5}{|l|}{ Plus uncategorised instruments } \\
\hline $\begin{array}{l}\text { Incorporated Societies } \\
\text { Hybrid }(\text { a) }\end{array}$ & & $\begin{array}{r}15 \\
2\end{array}$ & 16 & $\begin{array}{r}2275 \\
49\end{array}$ \\
\hline Total & & $\frac{2}{316}$ & $\frac{2}{20 ?}$ & $\frac{49}{42877^{(b)}}$ \\
\hline folar & & 316 & 382 & $42877^{(b)}$ \\
\hline
\end{tabular}

Notes:(a) In one case the arrangement covered an industrial union of workers and an incorporated society. In the other it covered two industrial unions and appeared to approach the form of a composite agreement.

(b) Maximum membership in this categorisation. 
Table 5 Industrial unions of workers involved in composite agreements

\begin{tabular}{|c|c|c|c|c|c|c|c|c|c|c|c|c|c|c|c|}
\hline $\begin{array}{c}\text { Composite } \\
\text { agreement } \\
\text { number }\end{array}$ & 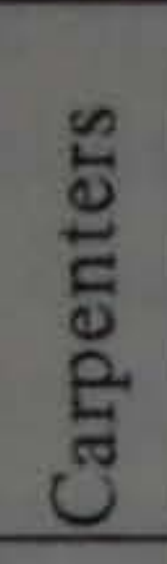 & 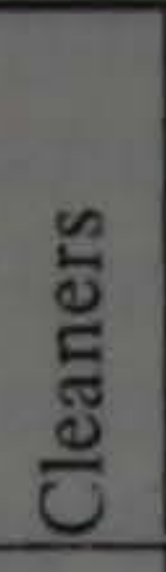 & 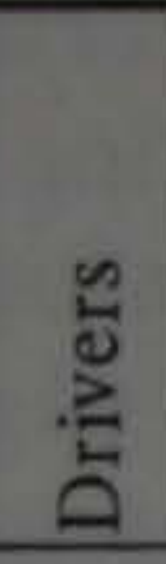 & 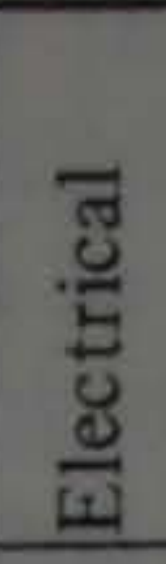 & 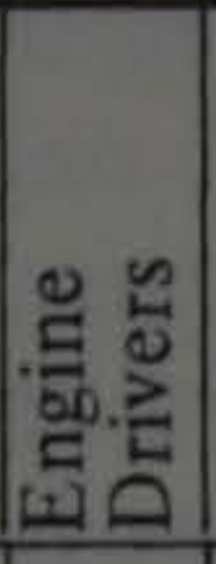 & 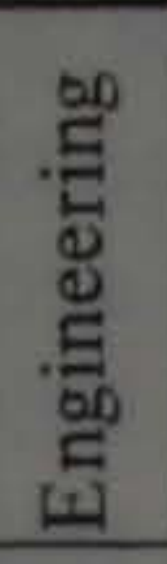 & 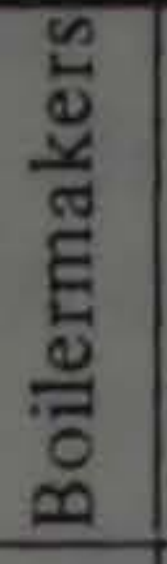 & 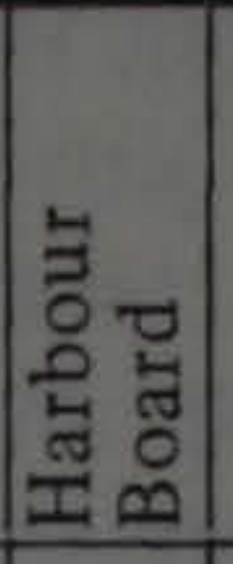 & 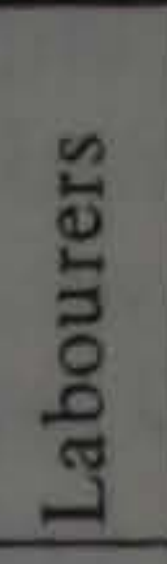 & 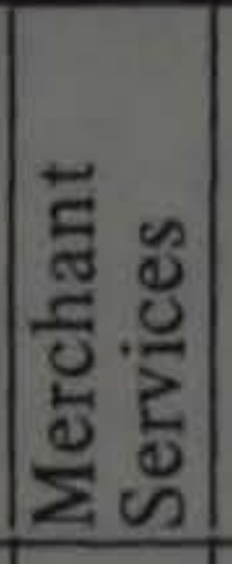 & 点 & $\begin{array}{l}\text { 岕 } \\
\text { है } \\
\text { E }\end{array}$ & 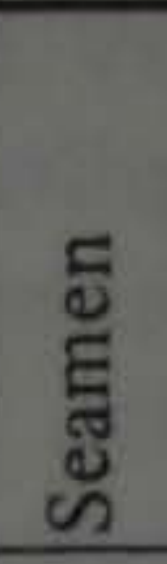 & 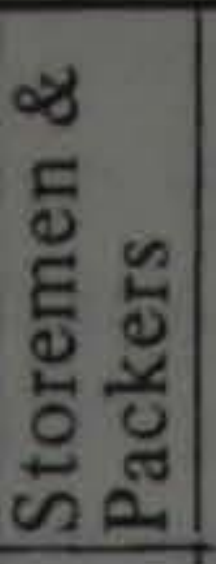 & $\begin{array}{c}\text { Total } \\
\text { unions }\end{array}$ \\
\hline 1 & & & & & & & & & & $*$ & & & $*$ & & 2 \\
\hline 2 & & & & & $*$ & & & & $*$ & & & & & & 2 \\
\hline 3 & & & & $*$ & & $*$ & & & $*$ & & & & & $*$ & 4 \\
\hline 4 & & $*$ & $*$ & & & & & & $*$ & & & & & & 3 \\
\hline 5 & & $*$ & $*$ & & & $*$ & & & & & & & & ax & 3 \\
\hline 6 & $*$ & & $*$ & $*$ & & & & & $*$ & & & & & $*$ & 5 \\
\hline 7 & & & & $*$ & & $*$ & & & & & & & & & 2 \\
\hline 8 & $*$ & & & & & & & & & & $*$ & & & 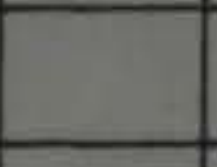 & 2 \\
\hline 9 & & & $*$ & & & & & & $*$ & & & & & 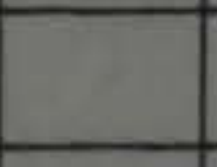 & 2 \\
\hline 10 & & $*$ & $*$ & $*$ & & & & & & & & & & $*$ & 4 \\
\hline 11 & & & $*$ & $*$ & & $*$ & & & & & & & & $*$ & 4 \\
\hline 12 & & & $*$ & & & - & & & & & $*$ & & & $*$ & 3 \\
\hline 13 & & & & & & * & & & & & & & & $*$ & 2 \\
\hline 14 & $*$ & & $*$ & $*$ & & $*$ & & & & & & & & $*$ & 5 \\
\hline 15 & $*$ & & & $*$ & & $*$ & & & $*$ & & & $*$ & & & 5 \\
\hline 16 & $*$ & & $*$ & $*$ & & & & & $*$ & & & & & & 4 \\
\hline 17 & $*$ & & & $*$ & & $*$ & & & & & & $*$ & & & 4 \\
\hline 18 & & $*$ & & $*$ & & & & & $*$ & & & & & & 3 \\
\hline 19 & & & & & & $*$ & $*$ & & & & & & & & 2 \\
\hline 20 & & & & $*$ & & $*$ & $*$ & & & & & & & & 3 \\
\hline 21 & & & $*$ & & & $*$ & & & $*$ & & & & & $*$ & 4 \\
\hline 22 & & & & & & & & * & & $*$ & & & & & 2 \\
\hline 23 & $*$ & & & & & & & & & & $*$ & $*$ & & & 3 \\
\hline 24 & & & & $*$ & $*$ & $*$ & & & & & & 1 & & & 3 \\
\hline 25 & $*$ & & & & & $*$ & & & & & $*$ & & & & 3 \\
\hline Frequency & 8 & 4 & 10 & 12 & 2 & 13 & 2 & 1 & 9 & 2 & 4 & 3 & 1 & 8 & \\
\hline
\end{tabular}

Source: Appendix, Book of Awards

\section{Commentary}

This study points to the importance of further analysis of voluntary collective bargaining in New Zealand. As far as registered agreements are concerned, the high volume of such instruments negotiated over the period under review disguises significant factors. Typically registered VCAs involve small work groups yet a significant proportion (over 20 percent) are associated with larger scale employment. Nonetheless, no more than 5 percent of the workforce are covered by these documents. They are largely concentrated in manufacturing and to a lesser extent in community and personal services. As might be expected, given the pattern of the country's industrial development, most registered VCAs and the greater proportion of employees covered by them, are to be found in the North Island.

An examination of trade union involvement shows that significant practitioners of voluntary collective bargaining within the formal system were clerical workers, drivers, electrical workers, engine drivers, engineers and allied workers, freezing workers, labourers and local body officers. In the special case of composite agreements, the most frequently involved groups were engineers, electrical workers, drivers, labourers, carpenters and 
storemen and packers.

The situation just described leaves an interesting question unanswered. Just how widespread is voluntary collective bargaining in New Zealand? Certainly it appears to cover relatively few employees under formal private sector negotiating procedures (i.e. involving registered documents). That, however, takes no account of informal and often unwritten arrangements which form a second, and even a third, tier in negotiations, notably in the meat freezing industry. Something more than a straw in the wind suggests that these unregistered agreements make up a very significant proportion (perhaps the majority) of voluntary agreements. The opinions of practitioners point to this but provide insufficient data for quantification. Informal voluntary negotiation may consequently provide a veritable treasure trove for future research. A hardening economic climate may narrow the gap between the formal and informal systems of negotiation. That gap, however, seems unlikely ever to be eliminated. By definition it must exist whenever the formal system is directed towards the negotiation of minimum terms and conditions of employment. For that reason alone, the form and scope of voluntary collective bargaining merits much closer attention.

If this interpretation of the current state of voluntary collective bargaining is correct, it has certain implications for researchers. First, the deviation between award rates and those actually paid under particular voluntary settlements (formal and informal) may be much more significant than discussions of "ruling rates" have so far suggested. The notional rates of pay thrown up by the current, limited range of wage statistics may thus be very misleading to both negotiators and government policy makers. Secondly, the logic of voluntary collective bargaining points to the assertion of some degree of initiative particularly in matters of joint problem solving. Such initiative has in fact been exerted in some VCAs. The review boards found in some local body registered VCAs take advantage of the permissive provision of section 115(3) of the Industrial Relations Act. In so doing they establish more flexible and extensive arrangements for the handling of disputes than are found in the statutory procedures of sections 116 and 117 (e.g. clause 25, Tauranga Electric Power Board Officers Agreement). Other informal procedures for handling disputes of rights point to similar initiatives (Miller, 1983).

The extent to which voluntary collective bargaining represents an assertion of initiative might be examined in a number of ways. Do these arrangements, particularly the informal settlements, establish trends or simply follow formal patterns? How innovative are the voluntary instruments in procedural matters? What is the pattern of work stoppages under voluntary settlements compared with that found under awards? Do voluntary settlements give rise to more stoppages in interest matters than over rights? These and other questions need probing in depth to spell out the real differences between industrial conciliation and arbitration and voluntary collective bargaining. They may well point to a way out of the current malaise infecting the New Zealand system of industrial relations.

\section{References}

Geare A.J. (1983) Formal collective arrangements in New Zealand private sector industrial relations New Zealand journal of industrial relations 8(1): $23-29$

Miller R.L. (1983) The resolution of disputes and grievances in New Zealand Wellington, Industrial Relations Centre, Victoria University of Wellington.

Walsh P.J. (1982) A critique of the conciliation and arbitration system. In F.J.L. Young (Ed) Three views of the New Zealand system of industrial relations Wellington, Industrial Relations Centre, Victoria University of Wellington.

Wilson M:A. (1981) Recent developments in New Zealand's industrial relations system New Zealand journal of industrial relations 6(1): 35-41.

Young F.J.L. (1975) New Zealand industrial relations - retrospect and prospect ILO/ Norad Industrial Relations Symposium for Asian Countries II. 